\title{
Tsykhanovska I. FORMATION OF FUNCTIONAL AND TECHNOLOGICAL PROPERTIES OF FLOUR DOUGH AND OUALITY OF FINISHED PRODUCTS IN THE TECHNOLOGY OF CUSTARD GINGERBREAD WITH THE USE OF «MAGNETOFOOD» FOOD ADDITIVE
}

Об’єктом дослідження є технологія заварних пряників з суміші житнього та пшеничного борошна з використанням харчової добавки «Магнетофуд». Для удосконалення технологї та отримання якісної продукції з подовженим терміном збереження свіжості використовують різні технологічні прийоми, у тому числі введення харчових добавок-поліпшувачів комплексної діï. Перспективними поліпшувачами харчових систем (зокрема, борошняних кондитерських мас) є нанодобавки, котрим притаманний широкий спектр функціонально-технологічних властивостей, в силу спещифічності їх фізико-хімічних характеристик внаслідок наномасштабного розміру $і$ квантово-механічних ефектів. 3 метою вивчення впливу харчової добавки «Магнетофуд» на функціонально-технологічні, фізико-хімічні та структурно-механічні властивості борошна, тіста та показники якості заварних пряників добавку «Магнетофуд» вводили у рецептурну суміш у вигляді жирової суспензї на етапі «замішування тіста». Встановлено, що введення добавки «Магнетофуд» в кількості 0,10\%; 0,15\%; 0,20\% до маси рецептурної суміші у порівнянні з контролем у зразках житньо-пшеничного борошна:

- збільшує: вологозв'язуючу здатність - на (21士1) \%; жироутримуючу здатність - на $(8,8 \pm 0,8) \%$; набухаючу здатність - на $(1,56 \pm 0,02) \mathrm{cm}^{3} / 2$; водопоглинальну здатність - на $(6,6 \pm 0,2) \%$; водоутри-

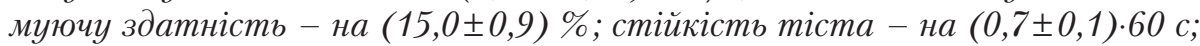

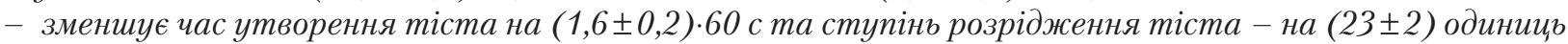
фарінографа;

- у зразках пряникового тіста збільшуе вологість на $(1,3 \pm 0,2) \%$;

- зменшуе густину тіста на $(0,7 \pm 0,1) \mathrm{r} / \mathrm{cm}^{3}$;

- підвищуе пластичну в'язкість на $(2,2 \pm 0,4)$ кПа.с у порівнянні з контролем;

- у зразках готових виробів збільшуе вихід на $(4,3 \pm 0,5) \%$, вологість на $(2,4 \pm 0,1) \%$, намочуваність

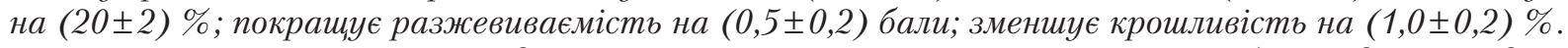

У порівнянні з аналогічними відомими покращувачами харчових систем нанооб'єкти, до яких відноситься нанопорошок на основі оксидів заліза $\mathrm{Fe}_{3} \mathrm{O}_{4}$ («Магнетофуд»), проявляють антиоксидантні, бактеріостатичні, сорбційні, емульгуючі, структуроутворюючі, волого- $і$ жироутримуючі властивості. Завдяки цьому забезпечується можливість отримання високих значень досліджених показників.

Ключові слова: харчова добавка «Магнетофуд», заварні пряники, житньо-пшеничне борошно, житньопшеничне тісто, показники якості.

\section{Introduction}

The confectionery industry is an industry that is developing rapidly and requires a large amount of resources, including a variety of raw materials, for the possibility of expanding the range of products taking into account the wishes of the consumer. It is important to study new types of raw materials and food additives improvers that provide new functional and technological properties of confectionery. These food ingredients have a chemical composition, structural components that can activate the technological process of production, and save raw materials, as well as improve nutritional value, quality indicators and shelf life of finished products. And this is an urgent problem today [1,2].

In this regard, it is of interest to search for new technological solutions and technological methods for improving the consumer properties of flour confectionery products. In recent years, there has been a tendency in the technology of flour confectionery products to develop and introduce the production of confectionery products using various food additives-improvers. All this allows to create a number of new advanced technologies and products, significantly expand their range, increase shelf life [2, 3]. 
Therefore, it is relevant to introduce a complex action in the prescription composition of the Magnetofood food additive to form new functional and technological properties of flour confectionery products, in particular, custard gingerbread from a mixture of wheat and rye flour. Magnetofood is an ultrafine powder with a particle size $(70 \ldots 80) \mathrm{nm}$ and with a large specific surface, high activity and specific properties: reducing, antioxidant, bacteriostatic, sorption, complex-forming, emulsifying, moisture-retaining, fat-soluble, water-binding. It is also an additional source of easily assimilated iron (II) [4-6].

\section{The object of research and its technological audit}

The object of research is the technology of custard gingerbreads from a mixture of rye and wheat flour using the Magnetofood food additive. To improve the technology and obtain high-quality products with a long shelf life of freshness, various technological methods are used, including the introduction of complex-improving food additives-improvers. Promising improvers of food systems (in particular, flour confectionery masses) are nanoadditives, which have a wide range of functional and technological properties, due to the specificity of their physicochemical characteristics due to nanoscale size and quantum mechanical effects.

This necessitates comprehensive research: functionaltechnological, physicochemical, structural and mechanical properties of flour, dough masses and quality and safety indicators of finished products.

\section{The aim and objectives of research}

The aim of research is the formation of the functional and technological properties of flour, dough and quality indicators of finished products in the technology of custard gingerbreads using the Magnetofood food additive.

To achieve this goal it is necessary to solve the following objectives:

1. To study the effect of the Magnetofood food additive on the functional and technological properties of rye-wheat flour and the functional, technological, physicochemical and structural-mechanical characteristics of the gingerbread dough.

2. To study the effect of Magnetofood food additive on the quality and safety indicators of finished gingerbread products, including the ability of gingerbread to stale and sorption properties.

3. To establish a rational amount of Magnetofood dietary additive and develop custard gingerbread recipe from a mixture of wheat and rye flour with Magnetofood additive.

\section{Research of existing solutions of the problem}

Now, in the practice of flour confectionery production, various food additives-improvers are used [4, 5] for:

- expanding the range and improving the quality of

flour confectionery [1, 2];

- regulation of the parameters of technological processes [3].

To improve technological parameters and extend the shelf life of flour confectionery, special groups of food additives are used: vitamin-mineral premixes, vitamins antioxidants, dietary fiber, micronutrient additives with a protective effect [6, 7]. The disadvantage of these additives is the narrow focus of the action.

In the production of flour confectionery, various dietary additives from plant materials (ginseng, Jerusalem artichoke, sea buckthorn, etc.) are widely used. They improve the consumer properties of finished products and contribute to an increase in the water-holding ability of flour confectionery masses $[8,9]$. The disadvantages of these additives are low functionality in terms of texture and physicochemical properties of finished products.

Now widespread are various polysaccharide additives obtained from natural ingredients: citrus fibers; hydrocolloids of plant origin, cellulose ethers $[10,11]$. Citrus fiber is a source of healthy fiber. The content of dietary fiber in them is from $88 \%$ to $93 \%$, including soluble fiber - about $20 \%[3,12]$. Thanks to such additives, it became possible to create low-calorie foods that retain the structural-mechanical and organoleptic characteristics of traditional analogues. However, they do not secure sufficient cookie porosity. Hydrocolloids: banana and apple powders; sea buckthorn meal; guar and xanthan gums [3, 11]; polydextrose is a polysaccharide consisting of glucose polymers with a low molecular weight $[3,10]$. Hydrocolloids are used to impart the desired viscosity or consistency, as well as to stabilize dispersed food systems (emulsions, suspensions). Many hydrocolloids, such as guar and xanthan gums, are soluble dietary fiber. And functional and technological ingredients that contribute to the improvement of water-holding ability and quality indicators. But their influence on the technological properties of the dough confectionery masses and finished products is insufficient.

In order to improve the rheological properties of flour confectionery masses and increase the water-absorbing ability of flour, natural powdery components obtained from dairy and egg products are used [9, 13]. Their disadvantage is the lack of multifunctionality.

Recently, various food additives obtained from recycled products have found application in the production of flour confectionery:

- leather, hooves, feathers [14];

- sub-products [15];

- seeds, bran [16];

- whey [17] and others.

However, these dietary additives are characterized by a narrow focus and do not exhibit a complex effect.

In order to improve the water holding capacity of flour confectionery masses and finished products, wheat-based bioadditives are used [18]. However, the yield and structural-mechanical indicators of the finished products do not improve.

To increase the water-absorbing ability of flour and the water-holding ability of flour confectionery masses in confectionery industries, bioadditives of various origin have also been proposed: soy, chickpeas [19]; enzymes, microalgae, etc. [20]. However, these additives have insufficient functionality for porosity and shape stability of finished products.

In recent years, in the confectionery industry, plantbased compounds containing phenols have been used to increase the water holding capacity of flour confectionery masses [21]. Their disadvantages are insufficient output and shelf life of finished products. 
Thus, an analysis of literary sources shows a lack of data on the use of nanopowder ingredients in the technology of flour confectionery products. To improve the quality, increase the shelf life, create new functional and technological properties of flour confectionery products, the Magnetofood food additives can be offered. In food systems, Magnetofood exhibits water-holding, fat-soluble, fat-emulsifying and stabilizing ability [22, 23]. Thus, the significant functional and technological potential of Magnetofood nanoparticles allows to recommend these food additives as an improver of food systems in flour confectionery products.

\section{Methods of research}

The work investigated the influence of the Magnetofood food additive on the functional-technological, physicochemical and structural-mechanical properties of flour, dough and quality indicators of finished products. Subjects of research - prototypes of custard gingerbread, made according to the traditional recipe for gingerbread «Leningradsky» (control - sample 1) [24], - Table 1.

Table 1

Consolidated recipe for Leningradsky gingerbread

\begin{tabular}{|l|c|c|c|}
\hline \multirow{2}{*}{ Raw materials } & $\begin{array}{c}\text { Mass } \\
\text { fraction of } \\
\text { solids, \% }\end{array}$ & $\begin{array}{c}\text { The consumption of raw materials } \\
\text { for semi-finished products } \\
\text { per 1 ton of finished products } \\
\text { (excluding packaging materials), kg }\end{array}$ \\
\cline { 3 - 4 } & & Natural & Solids \\
\hline Wheat flour 1 grade & 85.50 & 413.36 & 353.42 \\
\hline Seeded rye flour & 85.50 & 95.71 & 81.83 \\
\hline Granulated sugar & 99.85 & 230.89 & 230.54 \\
\hline Natural honey & 78.00 & 221.95 & 173.12 \\
\hline Margarine & 84.00 & 56.00 & 47.04 \\
\hline Melange & 27.00 & 11.70 & 3.16 \\
\hline Baking soda & 85.00 & 1.54 & 0.77 \\
\hline Ammonium carbonate & - & 7.28 & - \\
\hline Cocoa powder & 95.00 & 11.19 & 10.63 \\
\hline Cinnamon & 100.00 & 3.05 & 3.05 \\
\hline Palenque & 78.00 & 10.18 & 7.94 \\
\hline Total & - & 1068.97 & 917.62 \\
\hline
\end{tabular}

To develop a system with the necessary quality indicators, the mass fractions of Magnetofood additives were selected $-0.10 \%$ (sample 2), $0.15 \%$ (sample 3 ) and $0.20 \%$ (sample 4) by weight of the recipe mixture.

In the process of performing the experimental work, standard and generally accepted research methods were used:

- water-binding ability (WBA) of flour and flour mixtures was determined by the Yamazaki method [25];

- swelling ability (SA) - by changing the volume (before and after swelling) of a given mass of flour; water-clay ability (WCA) and rheological properties on the Brabender Farinography (Germany) according to DSTU 4111.1-2002 (ISO 5530-1: 1997.MOD) [26]; water-holding ability (WHA) and fat-holding ability (FHA) by centrifugation;

- moisture content of semi-finished products for custard gingerbreads and finished products was determined by the accelerated gravimetric method according to DSTU 4910:2008 [27];
- study of the adhesive strength of the dough is based on the method of uniform separation [28];

- rheological properties of the dough were determined on a rotational viscometer Volarovich RV-8 (Russia) in accordance with the methodology described in [26]; - determination of the strength properties of test dough samples was carried out on AR-4/1 penetrometers (Russia) by immersion of a cone with a cone opening angle of $30^{\circ}$ and $60^{\circ}$ according to the standard method [28];

- determination of the hardness of the gingerbread was carried out by the method of pressing a stamp [29, 30]; - alkalinity was determined by titration with an indicator according to DSTU 5024:2008;

- wet, crumbling and chewing properties were determined according to DSTU 5023:2008 and [29, 30];

- mass of baked products was determined in accordance with DSTU EN 45501:2007, and the packs were determined in accordance with $[25,26]$.

The list of microbiological indicators by which the quality control of brewed gingerbread samples was carried out was established, guided by the requirements of GOST 10444.12-88, GOST 10444.15-94, GOST 26668-85, GOST 26669-85, GOST 26670-91, GOST 27543-87, DSTU ISO 9308-1:2005. Microbiological analysis of gingerbread samples was carried out on the basis of SanPiN 42-123-4940-88 standards. For the organoleptic evaluation of products, a 5-point scale of DSTU 4683:2006 was applied.

\section{Research results}

In order to justify the rational mass fraction of the Magnetofood food additive in custard gingerbread, the functional and technological characteristics of rye-wheat flour, the physicochemical and rheological properties of the gingerbread dough made from it and the quality indicators of the finished products were evaluated.

The water-holding ability (WHA), fat-holding ability (FHA), water-binding ability (WBA), water-claying ability (WCA), swelling ability (SA) of prototypes of rye-wheat flour and the rheological properties of the dough made from it are investigated.

Table 2 shows the functional and technological indicators of prototypes of rye-wheat flour and dough made from it with different contents of the Magnetofood food additive.

Table 2

Functional and technological indicators of prototypes of rye-wheat flour and dough

\begin{tabular}{|c|c|c|c|c|}
\hline \multirow{2}{*}{ Indicator } & \multicolumn{4}{|c|}{ Prototypes of rye-wheat flour } \\
\hline & Sample 1 & Sample 2 & Sample 3 & Sample 4 \\
\hline WBA, \% & $232 \pm 1$ & $250 \pm 1$ & $256 \pm 1$ & $254 \pm 1$ \\
\hline FHA, \% & $82.0 \pm 0.8$ & $89.0 \pm 0.8$ & $92.0 \pm 0.8$ & $91.0 \pm 0.8$ \\
\hline $5 \mathrm{~A}, \mathrm{~cm}^{3} / \mathrm{g}$ & $2.65 \pm 0.02$ & $4.18 \pm 0.02$ & $4.25 \pm 0.02$ & $4.21 \pm 0.02$ \\
\hline WCA, \% & $67.0 \pm 0.2$ & $73.0 \pm 0.2$ & $73.8 \pm 0.2$ & $73.6 \pm 0.2$ \\
\hline WHA, \% & $87.0 \pm 0.9$ & $100.0 \pm 0.9$ & $104.0 \pm 0.9$ & $102.0 \pm 0.9$ \\
\hline $\begin{array}{l}\text { Dough formation time, } \\
\tau \cdot 60 \mathrm{~s}\end{array}$ & $6.0 \pm 0.2$ & $4.6 \pm 0.2$ & $4.4 \pm 0.2$ & $4.2 \pm 0.2$ \\
\hline Dough stability, $\tau \cdot 60 \mathrm{~s}$ & $7.9 \pm 0.1$ & $8.5 \pm 0.1$ & $8.7 \pm 0.1$ & $8.6 \pm 0.1$ \\
\hline $\begin{array}{l}\text { Dough dilution degree, } \\
\text { farinograph units }\end{array}$ & $70 \pm 2$ & $49 \pm 2$ & $45 \pm 2$ & $47 \pm 2$ \\
\hline
\end{tabular}


As can be seen from the Table 2 making additives «Magnetofood» in the amount of $0.10 \%, 0.15 \%, 0.20 \%$ by weight of the prescription mixture compared with the control (sample 1) increases:

- WBA - by $(21 \pm 1) \%$

- FHA - by $(8.8 \pm 0.8) \%$;

- SA - by $(1.56 \pm 0.02) \mathrm{cm}^{3} / \mathrm{g}$;

- WCA - by $(6.6 \pm 0.2) \%$;

- WHA - by $(15.0 \pm 0.9) \%$;

- dough stability - by $(0.7 \pm 0.1) \cdot 60 \mathrm{~s}$.

This is due to the structure-forming ability of Magnetofood nanoparticles, which contributes to better binding of water and fat and more durable retention of moisture and fat in the structure of the product. From the data of Table 2 it also follows that, compared with the control, the dough formation time is reduced by $(1.6 \pm 0.2) \cdot 60 \mathrm{~s}$ and the degree of dough dilution by $(23 \pm 2)$ units. This is due to the coordination and electrostatic action of Magnetofood nanoparticles.

The best effect is noted when the amount of Magnetofood additive is $0.15 \%$ by weight of the prescription mixture.

The results of studies of the physicochemical and structural-mechanical properties of the prototype gingerbread dough with different amounts of Magnetofood additives are given in Table 3 .

Tahle 3

Physico-chemical and structural-mechanical properties of gingerbread dough with various mass fractions of the Magnetofood food additive

\begin{tabular}{|c|c|c|c|c|}
\hline \multirow{2}{*}{ Indicator } & \multicolumn{4}{|c|}{ Gingerbread dough prototypes } \\
\hline & Sample 1 & Sample 2 & Sample 3 & Sample 4 \\
\hline Mass fraction of wet, \% & $24.3 \pm 0.2$ & $25.5 \pm 0.2$ & $25.7 \pm 0.2$ & $25.6 \pm 0.2$ \\
\hline Density, g/cm ${ }^{3}$ & $1.29 \pm 0.1$ & $1.23 \pm 0.1$ & $1.20 \pm 0.1$ & $1.21 \pm 0.1$ \\
\hline $\begin{array}{l}\text { Plasticity } \\
\text { (ultimate shear stress), } \mathrm{Pa}\end{array}$ & $505 \pm 2$ & $525 \pm 2$ & $529 \pm 2$ & $530 \pm 2$ \\
\hline Adhesive strength (steel), $\mathrm{kPa}$ & $2.7 \pm 0.1$ & $2.3 \pm 0.1$ & $2.0 \pm 0.1$ & $2.1 \pm 0.1$ \\
\hline $\begin{array}{l}\text { Plastic viscosity, } \mathrm{kPa} \cdot \mathrm{s} \\
\text { (at } \gamma=0,02 \mathrm{~s}^{-1} \text { ) }\end{array}$ & $7.5 \pm 0.4$ & $9.4 \pm 0.4$ & $9.9 \pm 0.4$ & $9.8 \pm 0.4$ \\
\hline Dough formation time, $\tau \cdot 60 \mathrm{~s}$ & $6.5 \pm 0.2$ & $4.9 \pm 0.2$ & $4.6 \pm 0.2$ & $4.5 \pm 0.2$ \\
\hline
\end{tabular}

Data of Table 3 shows that the introduction of Magnetofood additives in the amount of $0.10 \%, 0.15 \%, 0.20 \%$ by weight of the prescription mixture:

- reduces dough formation time by $(1.8 \pm 0.2) \cdot 60 \mathrm{~s}$;

- increases humidity by $(1.3 \pm 0.2) \%$;

- reduces the density of the dough by $(0.7 \pm 0.1) \mathrm{g} / \mathrm{cm}^{3}$ compared with the control (sample 1).

This is due to the «clusterophilism» of Magnetofood nanoparticles. It also increases: the ultimate shear stress by (23 \pm 2$) \mathrm{Pa}$; plastic viscosity by $(2.2 \pm 0.4) \mathrm{kPa} \cdot \mathrm{s}$ compared to the control. That is, the introduction of the Magnetofood additive leads to positive changes in the rheological properties of the dough, expressed in a decrease in the resistance of the dough samples to the deforming load, that is, an increase in ductility in proportion to the mass fraction of the Magnetofood additive. Also, with an increase in the mass fraction of Magnetofood additive, the adhesive strength decreases compared to the control by $(14.8 \pm 0.1) \%$ when $0.1 \%$ Magnetofood is added, by $(25.9 \pm 0.1) \%-0.15 \%$ of Magnetofood and by $(22.2 \pm 0.1) \%-0.2 \%$ of Magnetofood. This is due to the water-holding ability of the nanoparticle additives.
Data of Table 3 it follows that the best characteristics of the gingerbread dough were obtained with a mass fraction of Magnetofood additives $0.15 \%$ by weight of the recipe mixture. The results of the organoleptic quality assessment of the prototypes of the finished gingerbread are shown in Fig. 1.

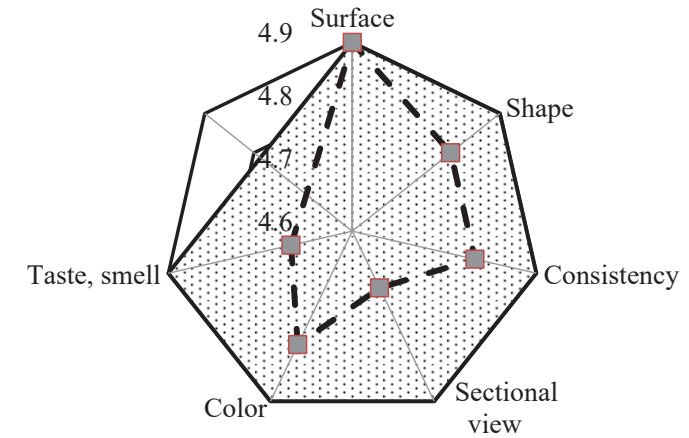

Sample 2 of $0.1 \%$ «Magnetofood»; - - Sample 1 - control

$a$

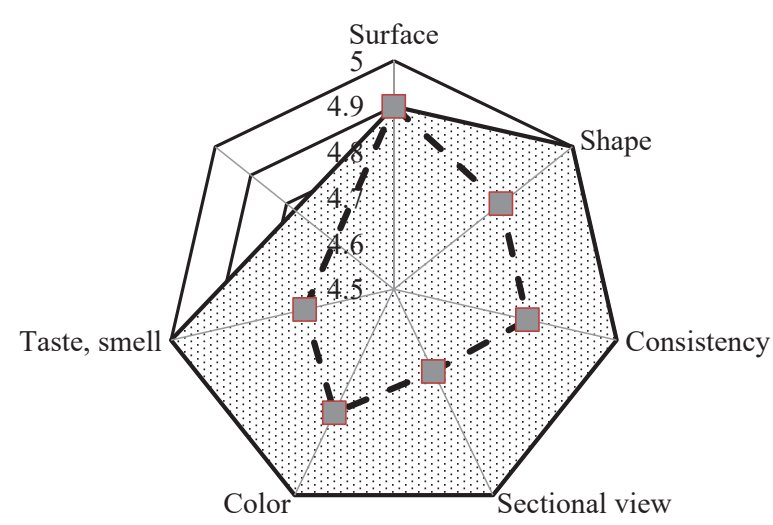

Sample 3 of $0.15 \%$ «Magnetofood»; $-\square$-Sample 1 - control

$b$

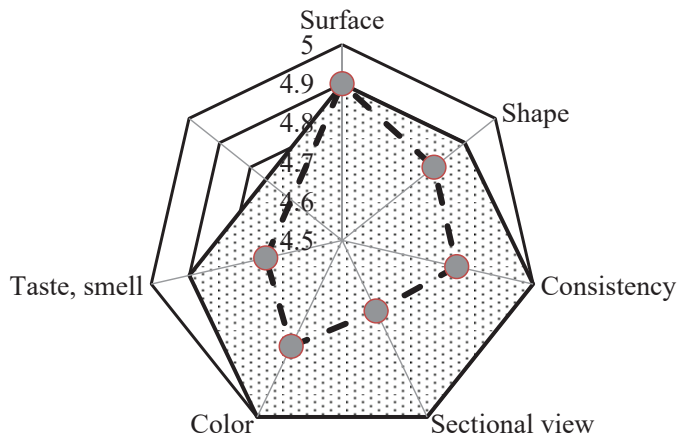

Sample 4 of $0.2 \%$ «Magnetofood»;

- -Sample 1 - control

Fig. 1. The quality level of the organoleptic properties of the prototypes of custard gingerbread compared to the control with a different mass fraction of the Magnetofood food additive: $a-0.1 \% ; b-0.15 \% ; c-0.2 \%$

As can be seen from Fig. 1, products from $0.15 \%$ Magnetofood dietary additive to the mass of the prescription mixture are better organoleptic quality indicators. The 
use of higher mass fractions of a food additive does not significantly affect the quality indicators, and also leads to an undesirable eclipse of products at a break.

According to the research results, a consolidated recipe for custard gingerbread «Kharkivsky» with the Magnetofood addition is proposed - Table 4 .

Table 4

Consolidated recipe for custard gingerbread Kharkivsky with the Magnetofood food additive

\begin{tabular}{|c|c|c|c|}
\hline \multirow[t]{2}{*}{ Raw material } & \multirow[t]{2}{*}{$\begin{array}{l}\text { Mass } \\
\text { fraction } \\
\text { of sol- } \\
\text { ids, \% }\end{array}$} & \multicolumn{2}{|c|}{$\begin{array}{l}\text { The consumption of raw materials } \\
\text { for semi-finished products } \\
\text { per } 1 \text { ton of finished products } \\
\text { (excluding packaging materials), kg }\end{array}$} \\
\hline & & Natural & Solids \\
\hline Wheat flour 1 grade & 85.50 & 412.36 & 352.42 \\
\hline Seeded rye flour & 85.50 & 95.71 & 81.83 \\
\hline Granulated sugar & 99.85 & 229.29 & 228.95 \\
\hline Natural honey & 78.00 & 221.95 & 173.12 \\
\hline Margarine & 84.00 & 56.00 & 47.04 \\
\hline Melange & 27.00 & 11.70 & 3.16 \\
\hline Baking sada & 85.00 & 1.54 & 0.77 \\
\hline Ammonium carbonate & - & 7.28 & - \\
\hline Cocoa powder & 95.00 & 9.99 & 9.45 \\
\hline Cinnamon & 100.00 & 3.05 & 3.05 \\
\hline Palenque & 78.00 & 10.18 & 7.94 \\
\hline Magnetofood food additive & 99.95 & 1.6 & 1.59 \\
\hline Total & - & 1068.97 & 917.62 \\
\hline Yield & 88.0 & 1000.00 & 880.00 \\
\hline \multicolumn{4}{|l|}{ 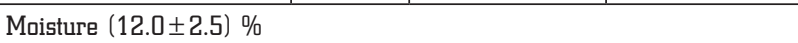 } \\
\hline
\end{tabular}

Table 5 shows the qualitative characteristics of the Kharkivsky gingerbread samples (with a rational content of Magnetofood additives $-0.15 \%$ by weight of the recipe mixture) compared with the control - Leningradsky gingerbread.

Tahle 5

Quality indicators of Kharkivsky custard gingerbread in comparison with custard gingerbread "Leningradsky" made using traditional technology

\begin{tabular}{|l|c|c|}
\hline \multirow{2}{*}{\multicolumn{1}{|c|}{ Indicator }} & \multicolumn{2}{c|}{ Custard gingerbread prototypes } \\
\cline { 2 - 3 } & $\begin{array}{c}\text { Leningradsky } \\
\text { gingerbread }\end{array}$ & $\begin{array}{c}\text { Kharkivsky ginger- } \\
\text { bread with 0.15 \% }\end{array}$ \\
\hline Mass fraction of wet, \% & $9.8 \pm 0.1$ & $12.2 \pm 0.1$ \\
\hline Alkalinity, \% & $2.0 \pm 0.1$ & $1.6 \pm 0.1$ \\
\hline Density, g/cm ${ }^{3}$ & $0.52 \pm 0.02$ & $0.41 \pm 0.02$ \\
\hline Wet, \% & $195 \pm 2$ & $215 \pm 2$ \\
\hline Crumbling, \% & $1.6 \pm 0.2$ & $0.6 \pm 0.2$ \\
\hline Fluidity, points & $4.5 \pm 0.2$ & $5.0 \pm 0.2$ \\
\hline Yield, \% & $84.4 \pm 0.5$ & $88.7 \pm 0.5$ \\
\hline Losses during heat treatment, \% & $9.9 \pm 0.2$ & $8.1 \pm 0.2$ \\
\hline
\end{tabular}

Data analysis in Table 5 shows that the Kharkivsky gingerbreads have better quality indicators compared to the Leningradsky gingerbreads made using traditional technology: - yield increases by $(4.3 \pm 0.5) \%$, humidity by $(2.4 \pm 0.1) \%$, wetting by $(20 \pm 2) \%$, chewing by $(0.5 \pm 0.2)$ point;

- density decreases by $(0.11 \pm 0.02) \mathrm{g} / \mathrm{cm}^{3}$; crumbling by $(1.0 \pm 0.2)$ losses during heat treatment by $(1.8 \pm 0.2) \%$; alkalinity by $(0.4 \pm 0.1)$.
The ability to staling of Kharkivsky gingerbread during storage was investigated by the tensometric method. The products were stored for a regulated period of 30 days at a temperature of $(18 \pm 2){ }^{\circ} \mathrm{C}$. The sorption properties of the Kharkivsky and Leningradsky gingerbreads prepared according to a traditional recipe are shown in Fig. 2.

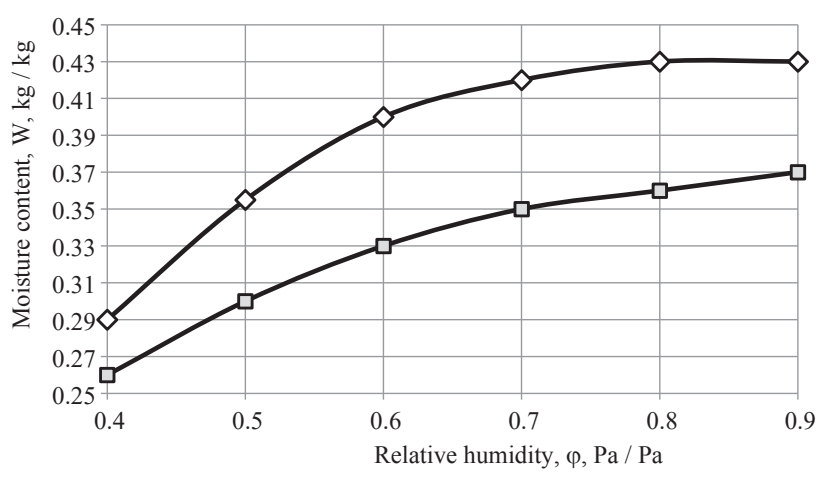

$\curvearrowright$ Kharkivsky gingerbreads with $0.15 \%$ of Magnetofood $\rightarrow$-Leningradsky gingerbreads

Fig. 2. Sorption isotherms of Leningradsky and Kharkivsky gingerbread at a temperature of (20 \pm 2$)^{\circ} \mathrm{C}$

An analysis of the sorption isotherms of the Kharkivsky and Leningradsky gingerbreads (Fig. 2) shows that the introduction of Magnetofood contributes to the retention of bound water in the product. At $\varphi=0.7$ (70\% relative humidity in the room), the amount of bound water in Kharkivsky gingerbread is $42 \%$, and in Leningradsky gingerbread $-35 \%$. This helps to extend the shelf life of the freshness of products from the Magnetofood food additive.

Microbiological quality indicators of custard gingerbread samples were investigated. In the Table 6 shows the results of microbial contamination of the surface of gingerbread samples immediately after manufacture and after storage at a temperature of $(18 \pm 5){ }^{\circ} \mathrm{C}$ for 30 days at a relative humidity of $\varphi=(75 \pm 2) \%$.

Table 6

Microbiological indicators of Kharkivsky custard gingerbread with Magnetofood food additive compared to Leningradsky gingerbread made using traditional technology during storage

\begin{tabular}{|c|c|c|c|}
\hline \multirow[b]{2}{*}{ Indicator } & \multirow{2}{*}{$\begin{array}{l}\text { Norma- } \\
\text { tive }\end{array}$} & \multicolumn{2}{|c|}{ Gingerbread, $\varphi=(75 \pm 2) \%$} \\
\hline & & $\begin{array}{l}\text { Leningradsky } \\
\text { gingerbread }\end{array}$ & $\begin{array}{l}\text { Kharkivsky } \\
\text { gingerbread }\end{array}$ \\
\hline $\begin{array}{l}\text { NMAFAM (number of mesophi- } \\
\text { lic aerobic and facultative an- } \\
\text { aerobic microorganisms), CFU } \\
\text { (colony forming units)/g, im- } \\
\text { mediately/after } 30 \text { days }\end{array}$ & $1.0 \cdot 10^{3}$ & $\begin{array}{c}\text { Not re- } \\
\text { vealed } / 4.0 \cdot 10^{2}\end{array}$ & $\begin{array}{c}\text { Not ге- } \\
\text { vealed/4.0.10 }\end{array}$ \\
\hline $\begin{array}{l}\text { Yeast } \mathrm{CFU} / \mathrm{g} \text {, immediately/after } \\
30 \text { days }\end{array}$ & 50 & $\begin{array}{c}\text { Not re- } \\
\text { vealed/8.0 }\end{array}$ & Not revealed \\
\hline $\begin{array}{l}\text { Bacteria of the group of Esche- } \\
\text { richia coli) (coliforms), } 1.0 \text { g, } \\
\text { immediately/after } 30 \text { days }\end{array}$ & $\begin{array}{c}\text { Not } \\
\text { allowed }\end{array}$ & Not revealed & Not revealed \\
\hline Immediately/after 30 days & $\begin{array}{c}\text { Not } \\
\text { allowed }\end{array}$ & Not revealed & Not revealed \\
\hline $\begin{array}{l}\text { Pathogenic microorganisms, in- } \\
\text { cluding bacteria of the genus } \\
\text { Salmonella, in } 25 \text { g, immedia- } \\
\text { tely/after } 30 \text { days }\end{array}$ & 50 & $\begin{array}{c}\text { Not re- } \\
\text { vealed/12.0 }\end{array}$ & $\begin{array}{c}\text { Nat re- } \\
\text { vealed/4.0 }\end{array}$ \\
\hline
\end{tabular}

From the data of Table 6 it follows that the introduction of the Magnetofood food additive reduces the con- 
tamination of the surface of the Kharkivsky gingerbread: NMAFAM by 10 times, yeast by 4 times, molds by 3 times compared with the control (Leningradsky gingerbread).

That is, the Magnetofood dietary additive suppresses the development of microorganisms on the surface of Kharkivsky gingerbread.

\section{SWOT analysis of research results}

Strengths. It has been established that the most strengths of flour confectionery products using the Magnetofood food additive are:

- uniqueness of the offer;

- patent protection;

- improvement of consumer characteristics;

- engthening the shelf life of freshness, resource conservation;

- cost reduction and optimization of the weight and volume of finished products due to the «clusterophilicity», water and fat-soluble ability of nanoparticles (which helps to reduce losses during heat treatment and increase yield).

Weaknesses. The weaknesses of the study include:

- low level of consumer information about new products and manufacturers' risks in the case of introducing new products, in particular the complexity of the calculation; - increase in energy consumption for the production of food additives.

Opportunities. According to the strategic prospects for promoting new products on the market, they are mainly determined by the growth of the nanotechnology and nanoproducts market, as well as by the demand for introducing nano-research results in the food sector.

Threats. The main threats to the sale of products using the Magnetofood food additive are the low level of financing of innovative projects and the unresolved nature of technology transfer issues.

\section{Conclusions}

1. It was found that the introduction of Magnetofood additives in an amount of $0.10 \% ; 0.15 \% ; 0.20 \%$ by weight of the prescription mixture compared to the control:

1) rye-wheat flour increases: WBA - by $(21 \pm 1) \%$; FHA - by $(8.8 \pm 0.8) \%$; SA - by $(1.56 \pm 0.02) \mathrm{cm}^{3} / \mathrm{g}$; WCA by $(6.6 \pm 0.2) \%$; WHA - by $(15.0 \pm 0.9) \%$;

2) rye-wheat dough:

- increases: dough stability at $(0.7 \pm 0.1) \cdot 60 \mathrm{~s}$, humidity at $(1.3 \pm 0.2) \%$, ultimate shear stress at $(23 \pm 2) \mathrm{Pa}$ and plastic viscosity at $(22 \pm 0.4) \mathrm{kPa} \cdot \mathrm{s}$;

- reduces the time of dough formation by $(1.6 \pm 0.2) \cdot 60 \mathrm{~s}$, the degree of dilution of the dough by $(23 \pm 2)$ units of the farinograph, the density of the dough by $(0.7 \pm 0.1) \mathrm{g} / \mathrm{cm}^{3}$, the adhesive strength by $(14.8 \ldots 25.9) \%$ of the surface of steel.

2. It is proved that the Kharkivsky gingerbread using Magnetofood additives have the best organoleptic properties and quality and safety indicators in comparison with the Leningradsky gingerbread made using traditional technology: - yield increases by $(4.3 \pm 0.5) \%$, humidity by $(2.4 \pm 0.1) \%$, wetting by $(20 \pm 2) \%$, fluidity by $(0.5 \pm 0.2)$ point; - density decreases by $(0.11 \pm 0.02) \mathrm{g} / \mathrm{cm}^{3}$; crumbling by (1.0 \pm 0.2$)$ losses during heat treatment by $(1.8 \pm 0.2) \%$; alkalinity by $(0.4 \pm 0.1)$.
It is determined that Magnetofood nanoparticles contribute to the retention of moisture in the product, increasing the amount of bound water by $(7.0 \pm 1) \%$ in Kharkivsky gingerbread compared to Leningradsky gingerbread.

3. A rational amount of the Magnetofood food additive has been determined, which is $0.15 \%$ by weight of the prescription mixture. The Kharkivsky gingerbread custard recipe was compiled from a mixture of wheat and rye flour with the addition of the Magnetofood food additive.

The obtained results give reason to recommend the Magnetofood food additive as a stabilizer, structure-forming agent and improver of flour confectionery products.

\section{References}

1. Panov, D. P. (2007). Obogaschenie produktov pitaniya massovogo potrebleniya. Pischeoyie ingredientyi, syire i dobavki, 1, 30-31.

2. Obzor ryinka hlebobulochnyih i konditerskih izdeliy Ukrainyi (2012). Hlebopekarskoe i konditerskoe delo, 3, 6.

3. Renzyaeva, T. V., Tuboltseva, A. S., Ponkratova, E. K., Lugovaya, A. V., Kazantseva, A. V. (2014). Functional and technological properties of powdered raw materials and food additives for confectionary. Tehnika i tehnologiya pischevyih proizvodstv, 4, 43-49

4. Tsihanovska, I. V., Demidov, I. M., Barsova, Z. V., Pavlotska, L. F. (2015). Investigation of the oxidative and thermal transformations processes in the system «oil - lipids-magnetite suspension». Progresivna tehnika ta tehnologiyi harchovih virobnitstv restorannogo gospodarstva i torgivli, 1 (21), 353-362.

5. Ilyuha, N. G., Barsova, Z. V., Kovalenko, V. A., Tsihanovskaya, I. V. (2010). Tehnologiya proizvodstva i pokazateli kachestva pischevoy dobavki na osnove magnetita. EasternEuropean Journal of Enterprise Technologies, 6 (10 (48)), 32-35. Available at: http://journals.uran.ua/eejet/article/view/5847

6. Tsykhanovska, I., Evlash, V., Alexandrov, A., Lazarieva, T., Svidlo, K., Gontar, T. (2017). Design of technology for the rye-wheat bread «Kharkivski rodnichok» with the addition of polyfunctional food additive «Magnetofood». Eastern-European Journal of Enterprise Technologies, 6 (11 (90)), 48-58. doi: http://doi.org/10.15587/1729-4061.2017.117279

7. Mingaleeva, Z., Starovoytova, O. et. al. (2007). Ispolzovanie antiokislitelnyih dobavok v proizvodstve muchnyih konditerskih izdeliy. Hleboproduktyi, 11, 52-53.

8. Tamazova, S. U., Lisovoy, V. V., Pershakova, T. V., Kasimirova, M. A. (2016). Food supplements based on vegetable raw materials in the production of baked goods and pastries. Polythematic Online Scientific Journal of Kuban State Agrarian University, 122 (8), 1-8. doi: http://doi.org/10.21515/1990-4665-122-076

9. Roslyakov, Yu. F., Vershinina, O. L., Gonchar, V. V. (2016). Scientific development for the baking and confectionery industry. Tehnologii pischevoy i pererabatyivayuschey promyishlennosti APK-produktyi zdorovogo pitaniya, 6, 1-6.

10. Tsitrusovyie volokna Herbacel AQ Plus - tip N: spetsifikatsii dlya pischeoyih dobavok $i$ retsepturyi (2013). Available at: http:// specin.ru/kletchatka/109.htm

11. Gorshunova, K. D., Semenova, P. A., Bessonov, V. V. (2012) The interaction of hydrocolloids and water-soluble vitamins at designing of the enriched foodstuff. Food industry, 11, 46-49.

12. Renzyaeva, T. V., Poznyakovskiy, V. M. (2009). Vodouderzhivayuschaya sposobnost syirya $\mathrm{i}$ pischevyih dobavok $\mathrm{v}$ proizvodstve muchnyih konditerskih izdeliy. Hranenie i pererabotka selhozsyirya, 8, 35-38.

13. Buldakov, A. (2008). Pischevyie dobavki: Spravochnik. Moscow: SPb., 280.

14. Martins, Z. E., Pinho, O., Ferreira, I. M. P. L. V. O. (2017). Food industry by-products used as functional ingredients of bakery products. Trends in Food Science E Technology, 67, 106-128. doi: http://doi.org/10.1016/j.tifs.2017.07.003

15. Lai, W. T., Khong, N. M. H., Lim, S. S., Hee, Y. Y., Sim, B. I., Lau, K. Y., Lai, O. M. (2017). A review: Modified agricultural by-products for the development and fortification of food products and nutraceuticals. Trends in Food Science E Technology, 59, 148-160. doi: http://doi.org/10.1016/j.tifs.2016.11.014 
16. Dziki, D., Różyło, R., Gawlik-Dziki, U., Świeca, M. (2014). Current trends in the enhancement of antioxidant activity of wheat bread by the addition of plant materials rich in phenolic compounds. Trends in Food Science \& Technology, 40 (1), 48-61. doi: http://doi.org/10.1016/j.tifs.2014.07.010

17. Torres-León, C., Rojas, R., Contreras-Esquivel, J. C., SernaCock, L., Belmares-Cerda, R. E., Aguilar, C. N. (2016). Mango seed: Functional and nutritional properties. Trends in Food Science $\&$ Technology, 55, 109-117. doi: http://doi.org/10.1016/ j.tifs.2016.06.009

18. Bharath Kumar, S., Prabhasankar, P. (2014). Low glycemic index ingredients and modified starches in wheat based food processing: A review. Trends in Food Science \& Technology, 35 (1), 32-41. doi: http://doi.org/10.1016/j.tifs.2013.10.007

19. Ngemakwe, P. N., Le Roes-Hill, M., Jideani, V. (2014). Advances in gluten-free bread technology. Food Science and Technology International, 21 (4), 256-276. doi: http://doi.org/10.1177/ 1082013214531425

20. Bird, L. G., Pilkington, C. L., Saputra, A., Serventi, L. (2017) Products of chickpea processing as texture improvers in glutenfree bread. Food Science and Technology International, 23 (8), 690-698. doi: http://doi.org/10.1177/1082013217717802

21. García-Segovia, P., Pagán-Moreno, M. J., Lara, I. F., MartínezMonzó, J. (2017). Effect of microalgae incorporation on physicochemical and textural properties in wheat bread formulation. Food Science and Technology International, 23 (5), 437-447. doi: http://doi.org/10.1177/1082013217700259

22. Tsykhanovska, I., Evlash, V., Alexandrov, A., Lazarieva, T., Svidlo, K., Gontar, T. et. al. (2018). Substantiation of the mechanism of interaction between biopolymers of rye-and-wheat flour and the nanoparticles of the magnetofood food additive in order to improve moisture-retaining capacity of dough. Eastern-European Journal of Enterprise Technologies, 2 (11 (92)), 70-80. doi: http://doi.org/10.15587/1729-4061.2018.126358
23. Tsykhanovska, I., Evlash, V., Alexandrov, A., Lazareva, T., Svidlo, K., Gontar, T. et. al. (2018). Investigation of the moisture-retaining power of rye-wheat gluten and flour with polyfunctional food supplement «MagnetoFood». EUREKA: Life Sciences, 2, 67-76. doi: http://doi.org/10.21303/25045695.2018.00611

24. Pavlov, A. V. (1998). Sbornik retseptur muchnyih konditerskih $i$ bulochnyih izdeliy dlya predpriyatiy obschestvennogo pitaniya. Saint Petersburg: Gidrometeoizdat, 450

25. Royter, I. M., Demchuk, A. P., Drobot, V. I. (1977). Novyie metodyi kontrolya hlebopekarnogo proizvodstva. Kyiv: Tehnika, 191.

26. Paschenko, L. P., Sanina, T. V., Stolyarova, L. I. et. al. (2007). Praktikum po tehnologii hleba, konditerskih i makaronnyih izdeliy (tehnologiya hlebobulochnyih izdeliy). Moscow: Kolos, 215.

27. DSTU 4910:2008. Virobi konditerski. Metodi viznachennya masovih chastok vologi ta suhih rechovin. Vzamen GOST 5900-73; vved. 2009-01-01. Kyiv: Derzhspozhivstandart Ukrayini, 14.

28. Pivovarov, P. P., Pogozhih, M. I., Polevich, V. V. et. al. (2006) Metodichniy posIbnik z reologIchnih metodiv doslidzhennya sirovini ta harchovih produktiv, avtomatizatsiya rozrahunkiv reologichnih harakteristik. Kharkiv: KhSUFT, 150.

29. GOST 24901-2014. Pechene. Obschie tehnicheskie usloviya (2015). Moscow: Standartinform, 12.

30. Hvostenko, E. V., Solodenko, G. S. (2013). Stabilizatsiya kachestva zavarnyih pryanikov iz bezamiloznoy muki v protsesse hraneniya. Problemy formuvannya zdorovoho sposobu zhyttya u molodi. Odesa: ONATH, 143-144.

Tsykhanovska Iryna, PhD, Associate Professor, Department of Food and Chemical Technologies, Ukrainian Engineering Pedagogics Academy, Kharkiv, Ukraine, e-mail: cikhanovskaja@gmail.com, ORCID: http://orcid.org/0000-0002-9713-9257 